\title{
Comparison of three regionalization techniques for predicting streamflow in ungaged watersheds in Nebraska, USA using SWAT model
}

\author{
Michael W. Van Liew, Aaron R. Mittelstet \\ (Department of Biological Systems Engineering, University of Nebraska, Lincoln, NE 68583, USA)
}

\begin{abstract}
This study compared three approaches, regional averaging, nearest neighbor, and donor techniques, to regionalize parameters in the Soil and Water Assessment Tool (SWAT) on eleven watersheds located in the Dissected Plains, Plains, and Rolling Hills Landforms in the eastern portion of the State of Nebraska, USA. Within the Rolling Hills Landform, three watersheds were randomly selected as calibration watersheds while two were randomly selected as validation watersheds. Two watersheds were randomly selected as calibration watersheds while one was randomly selected as a validation watershed within each of the Dissected Plains and Plains Landforms. The seven calibration watersheds were used to provide the necessary calibrated parameter sets to execute each of the regional approaches, while the four validation watersheds were used to assess the impact of applying each of these approaches to an uncalibrated watershed. Percent Bias (PBIAS) and the Nash Sutcliffe Coefficient of Efficiency (NSE) were used to assess model performance. Test results of this study show that all three methods performed poorly, since the majority of watersheds among each method tested exhibited PBIAS values greater than $\pm 25 \%$ and/or NSE values less than 0.50 , which were considered to be unsatisfactory in terms of model performance. The average regionalization, nearest neighbor and donor methods resulted in only four (two calibration and two validation), zero and one satisfactory set of simulated watershed results, respectively. The findings from this study indicate that although each watershed was successfully calibrated with NSE values ranging from 0.51 to 0.84 , none of the three regionalization methods provided suitable calibration data sets to define parameter values for performing satisfactory simulations on ungaged watersheds across the eastern Nebraska landscape.
\end{abstract}

Keywords: SWAT model, watersheds, hydrology, model calibration, parameter regionalization, Nebraska ungaged watersheds DOI: $10.25165 /$ j.ijabe. 20181103.3528

Citation: Van Liew M W, Mittelstet A R. Comparison of three regionalization techniques for predicting streamflow in ungagged watersheds in Nebraska, USA using SWAT model. Int J Agric \& Biol Eng, 2018; 11(3): 110-119.

\section{Introduction}

High-speed computer and Geographical Information System (GIS) technological advances during the past three decades have led to the development of a host of ecohydrological watershedsimulation models ${ }^{[1-4]}$. These models have the capability to address a range of water resource and water quality issues such as water availability and allocation, the impact of climate and land use change, and the implementation of best management practices. In order to provide accurate streamflow and water-quality simulations, these models must be calibrated from available measured data that have been collected in a watershed. More recently, user-friendly derivatives of existing models have also been developed on a statewide basis to enable water-quality specialists, extension agents, and stakeholders to predict the fate and transport of constituents, such as sediment, nutrients, and pesticides from the landscape to the watershed outlet. These newly developed tools also require calibration for accurate predictions at the county or regional level within a given state. Because measured data such as daily streamflow values or periodic measurements of water quality constituents are often scarce or nonexistent on watersheds within a particular region, techniques must be applied to these ungaged

Received date: $2017-05-29$

Accepted date: 2018-04-17

Biographies: Michael W. Van Liew, PhD, Water Quality Extension Educator, Biological Systems Engineering, University of Nebraska, Lincoln, NE 68583, USA. Email: vanliew@windstream.net.

*Corresponding author: Aaron R. Mittelstet, PhD, Assistant Professor, Biological Systems Engineering, University of Nebraska, 245 L.W. Chase Hall, Lincoln, NE 68583, USA. Tel: +1-402-471-4255, Email: amittelstet2@unl.edu. catchments so that parameter values can be adequately estimated. The process whereby parameters are transferred from neighboring or adjacent watersheds to a watershed of interest is referred to as regionalization ${ }^{[5]}$.

Various techniques may be used to regionalize parameters within a given simulation model. One commonly used technique is referred to as regional averaging, whereby model parameters from calibrated watersheds within a given region are averaged and then applied to uncalibrated watersheds within that region. A second regionalization method, referred to as nearest neighbor, is based on the spatial distance between an ungaged watershed of interest and nearby calibrated watersheds, which are assumed to have similar watershed attributes and corresponding parameter values. A third regional technique is to estimate model parameters independently from a least squared linear regression analysis based on attributes of calibrated watersheds within a given region. A fourth regionalization method commonly reported in the literature is the donor approach. The basis of this group is to identify a donor watershed within a given region that is most similar in terms of its watershed attributes to the ungaged watershed of interest, and to transpose the calibrated parameter set to that watershed. A fifth regionalization method is kriging, which interpolates between spatially autocorrelated variables.

Numerous examples of regionalization assessments to estimate model parameters are found in the literature. For example, Vandewiele and Elias ${ }^{[6]}$ used kriging and neighboring basin techniques to compute parameter values for 75 watersheds in Belgium. They reported that kriging gave satisfactory results in $72 \%$ of the selected watersheds, while the neighboring basin 
approach gave satisfactory results in only $44 \%$ of the watersheds. Merz and Bloschl ${ }^{[7]}$ performed a detailed analysis to regionalize catchment parameters on 308 watersheds in Austria. They found that the use of average parameters on watershed neighbors immediately upstream and downstream of an ungaged watershed (spatial proximity approach) generally performed better than a kriging approach to regionalization. They also reported that the spatial proximity approach performed significantly better than regression methods that were based on catchment attributes. Burn and Boorman ${ }^{[8]}$ used a clustering algorithm based on physical characteristics of a watershed to estimate unit hydrograph time to peak and percentage of runoff on ungaged watersheds in the United Kingdom. They found that this method gave better results than the use of multivariate regression techniques for estimating the two watershed parameters.

Regionalization of an ecohydrological model sometimes involves a two-step process whereby watershed model parameters are initially estimated and then various approaches are used to relate those model parameters to drainage basin characteristics. Fernandez et al. ${ }^{[9]}$ used a different strategy to regionalization by implementing both of these steps concurrently. They calibrated 33 watersheds in the southeast region of the US simultaneously, with the goal of obtaining both accurate model simulations and good relationships between watershed model parameters and basin characteristics. They reported that even though the regional calibration led to very good regional relationships between model parameters and basin characteristics, these refined regional relationships did not result in improved streamflow simulations for ungaged watersheds.

Heuvelmans et al. ${ }^{[10]}$ conducted a study to compare parameter estimates obtained from linear regression techniques versus artificial neural networks (ANNs). In their investigation, they applied the Soil and Water Assessment Tool (SWAT) to 25 watersheds ranging in size from about $2-210 \mathrm{~km}^{2}$ in the Scheldt River Basin in Belgium. Five of the seven parameters used in their study were dependent on land use as a watershed descriptor. By regionalizing three surface and four subsurface parameters in the model, they found that ANNs provided more accurate parameter estimates than linear regression expressions, if the non-linearities simulated by the ANNs have physical meaning and if the physical descriptors of the watershed of interest lie within the range of the descriptor values of the sites used for the construction of the ANNs. In addition, Heuvelmans et al. ${ }^{[10]}$ reported that the uncertainty of regionalized parameters was somewhat higher for ANNs than for regression equations; this uncertainty ranges between 15 and 30\% for all seven parameters and regionalization techniques.

In another European study, Sellami et al. ${ }^{[11]}$ investigated uncertainty analysis in modeled parameters for Mediterranean watersheds in Southern France. In their study they applied SWAT to the $280 \mathrm{~km}^{2}$. Thau watershed which is drained by ten streams that flow directly into a lagoon. In their study they used a sensitivity analysis on 27 parameters in the SWAT model to determine which are the ten most sensitive. Sellami et al. ${ }^{[11]}$ reported that for watersheds within the same cluster, ungaged watersheds can exhibit similar hydrologic behavior if they exhibit a high degree of similarity in their physical attributes and have received similar model parameter sets. They also found that within the same climatic and geographic region, watersheds that are very similar to each other exhibit a similar degree of prediction uncertainty.

Parajka et al. ${ }^{[12]}$ performed a very comprehensive regionalization study on catchment model parameters for 330 watersheds in Austria. They used 18 methods from 4 groups of regionalization approaches that included local and global averaging, spatial proximity, regression analysis, and donor contribution. Findings from their study suggest that all methods gave reasonably favorable performance for both the calibration and validation periods. The best results obtained using spatial and donor approaches gave median daily runoff Nash-Sutcliffe Coefficient of Efficiency (NSE) values of 0.62 and 0.61 , respectively, for validation watersheds used in their study. Gitau and Chaubey ${ }^{[13]}$ used global averaging and regression based parameters to evaluate model performance on ungaged watersheds in Arkansas using SWAT. Their findings show that the global averaging method gave monthly NSE values that ranged from 0.40 to 0.75 , while monthly NSE values for the regression approach ranged from 0.53 to 0.83 . Both methods gave results that were comparable to those obtained through calibration.

In another study using the SWAT model, Pagliero et $\mathrm{al}^{[14]}$ proposed a protocol with the objective of overcoming model calibration by using regional parameterization of the model and improving calibration transparency for overcoming identifiability problems. They applied SWAT to the $803000 \mathrm{~km}^{2}$ Danube River Basin (DRB) in Europe, delineated the basin at high resolution into 4663 subbasins, and implemented a regional calibration by relating hydrologic responses to watershed properties using a partial least squares regression analysis. They selected gaged watersheds that are representative of each region of the DRB and performed calibrations of selected watersheds to obtain a set of calibrated parameters that are representative of every hydrological region in the basin. Pagliero et al. ${ }^{[14]}$ then extrapolated a set of calibrated parameters to a corresponding region with the DRB. For four calibration and three validation regions, they reported monthly streamflow NSE values ranging from 0.65 to 0.75 and from 0.28 to 0.66 , respectively.

Daggupati et al. ${ }^{[15]}$ followed a protocol similar to Pagliero et $\mathrm{al}^{[14]}$ and simulated water and crop yields in one of the few reported model simulation investigations of the entire Missouri River Basins (MRB) located in the north central portion of the U.S. After obtaining satisfactory results from flow calibration at the head watersheds in their delineated project, they used a regionalization calibration approach to transfer the calibration parameter set from each head watershed was to the subwatersheds within eleven MRB regions. Daggupati et al. ${ }^{[15]}$ reported that observed and simulated water yields in the head watersheds and those in the validation locations were in close agreement for naturalized stream systems within the MRB.

Swain et al. ${ }^{[16]}$ used inverse distance weighted (IDW), kriging, global mean, regression and physical similarity to simulate streamflow in 32 catchments in Eastern and Southern India. Prior to using the regionalization approaches, they calibrated and validated each watershed with NSE values between 0.59 and 0.81 for the calibration period and 0.48 to 0.77 for the validation period. Of the five regionalization approaches, the global mean produced the poorest results with median NSE value of 0.44 and 0.39 for the calibration and validation periods, respectively. The best results were obtained from the IDW and kriging approaches with median NSE values of 0.58 and 0.59 , respectively.

SWAT has been used a limited number of times in the State of Nebraska. Watersheds located in the Nebraska Sandhills were modeled unsuccessfully by the Nebraska Natural Resource Commission ${ }^{[17]}$ and Daggupati et al. ${ }^{[18]}$ Their unsuccessful 
application of the SWAT model was attributed to the high groundwater storage levels, which contribute over $90 \%$ of the flow in the rivers. Woznicki et al. ${ }^{[19]}$ simulated streamflow well in the Tuttle Creek Lake watershed, located in Nebraska and Kansas while Van Liew et al. ${ }^{[20]}$ successfully modeled Logan and Shell Creeks in northeast Nebraska with NSE values of 0.82 and 0.88 for the calibration periods and 0.58 and 0.83 for the validation periods.

To date, no regionalization study using the SWAT model has been conducted in Nebraska. Therefore to better understand the potential for developing parameter regionalization in the SWAT model for ungaged watersheds in Nebraska, US, we implemented an investigation to assess various regionalization techniques. Specifically, the objective of this study was to evaluate the use of three regionalization methods for estimating parameter values in the SWAT ecohydrological model ${ }^{[21-23]}$ that could be applied to ungaged watersheds in the eastern portion of Nebraska. These methods were based on readily available watershed data and included 1) regional averaging, 2) nearest neighbor, and 3) donor techniques. These three methods were chosen for this study because they are among the more commonly used approaches for parameter regionalization reported in the literature.

\section{Materials and methods}

\subsection{Model setup}

SWAT was originally developed by the U.S. Department of Agriculture (USDA)-Agricultural Research Service (ARS) to predict the impact of land management practices on water, sediment, and nutrients in large ungaged basins ${ }^{[24-26]}$. The model is recognized globally as one of the premier simulation tools for addressing a host of water resource and water quality issues at a multiple scales. Hydrologic components that are simulated in the model include snow accumulation and melt, rainfall runoff partitioning, evapotranspiration, and surface, lateral, and ground water flow. Model simulations performed in SWAT are usually computed on a daily time step. SWAT is a distributed parameter model that partitions a watershed into a number of subbasins. Each subbasin delineated within the model is simulated as a homogeneous area in terms of climatic conditions, but with additional subdivisions within each subbasin to represent topography, soils, and land use types. Each of these subdivisions is referred to as a hydrologic response unit (HRU) and is assumed to be spatially uniform in terms of soil, land use, and slope. For this study the USDA-Natural Resource Conservation Service (NRCS) runoff curve number (CN2) $\operatorname{method}^{[27]}$ and the Hargreaves method ${ }^{[28]}$ were used to estimate surface runoff from daily precipitation and evapotranspiration, respectively. Model documentation is well formulated for SWAT, with considerable detail that is provided regarding model structure, algorithms, data input, and viewing of test results. SWAT version 2012 (SWAT2012) Revision 643 was used for this study, with input and output documentation for that version described by Arnold et al. ${ }^{[29]}$

Because SWAT is a physically based computational model, it depends upon quantitative data such Manning's roughness coefficient, leaf area index, plant heat units, soil particle size, hydraulic conductivity, soil bulk density, and the SCS Curve Number that may reflect highly varying conditions across a watershed. These data in turn are used to describe model processes such as plant growth and maturity, infiltration, evaporation, transpiration, changes in soil moisture, and the movement of surface runoff, lateral flow, and groundwater flow. As a distributed parameter model, SWAT has the capability of readily accounting for spatial and temporal variations in hydrologic response as a result of differences in the magnitude of topographic, soil, and land cover input variables across the landscape. Because of its robust structure, SWAT is a model that is highly suitable for performing streamflow simulations on watersheds with widely varying physiographic features, including studies related to regional parameterization.

\subsection{Calibration and Validation Watersheds}

The regional parameterization study used in this study was conducted only on watersheds in the eastern one-third of the State of Nebraska as shown in Figure 1. Watersheds used in this study exhibit a steep precipitation gradient that ranges from about $580 \mathrm{~mm}$ for the Verdigre River watershed to about $850 \mathrm{~mm}$ in the vicinity of the Little Nemaha River watershed. Topographic, soils, and land cover features of the eleven watersheds are presented in Table 1, while the location of the calibration and validation watersheds is shown in Figure 1. Most watersheds in this the study are predominantly overlain by silt loam or silty clay soils, with the exception of the sandy loam and loam soils that characterize the Beaver and Verdigre River watersheds. The percentage of range/pasture among the test watersheds ranges from $8 \%$ at Papillion, a partially urbanized watershed to the southeast of Omaha, to $100 \%$ at the 43 ha experimental pasture watershed at Clay Center ${ }^{[30,31]}$. Watersheds with at least two-thirds of the land cover designated as dryland or irrigated cropland include the Omaha, Rock, Shell, Turkey, and Weeping Water.

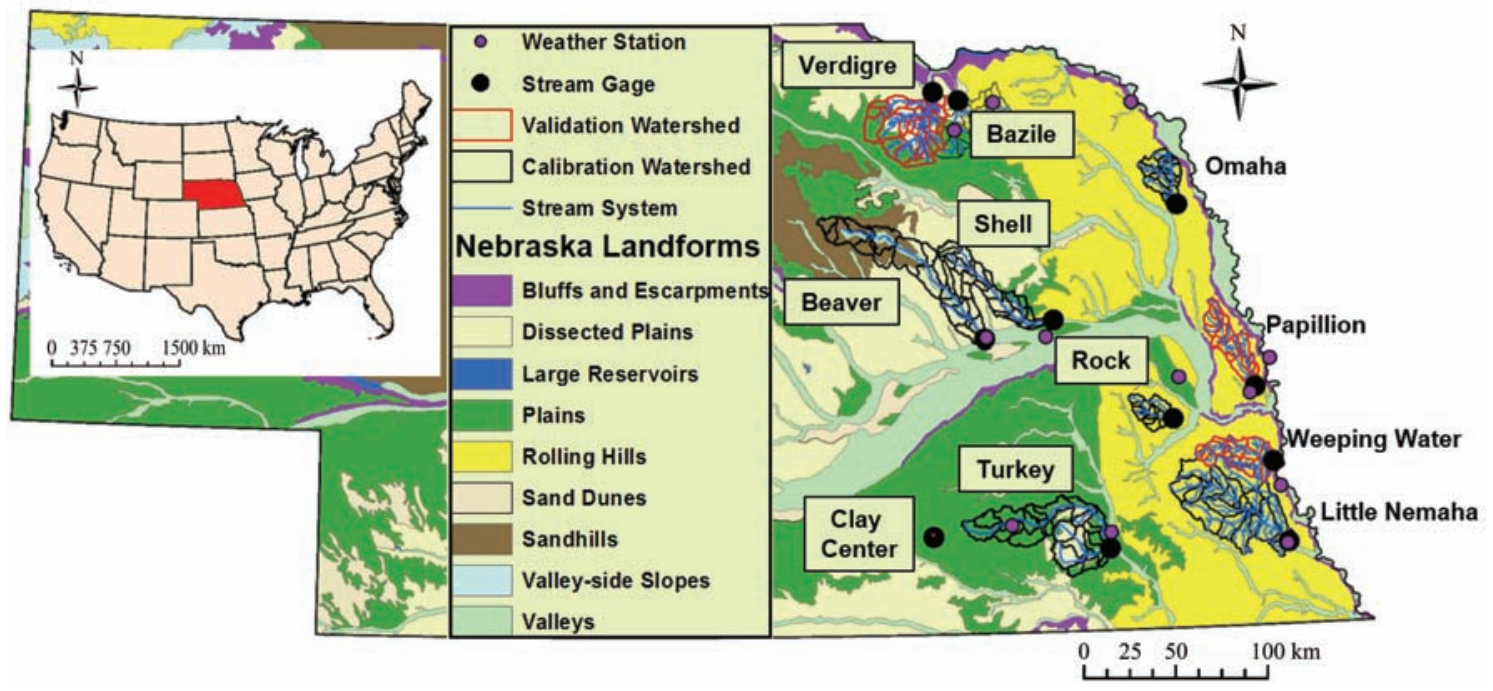

Figure 1 Location of the calibration and validation watersheds in eastern Nebraska 
Table 1 Watershed area, subareas in SWAT, topographic, soil, and land cover attributes for the 11 watersheds within the 3 regions

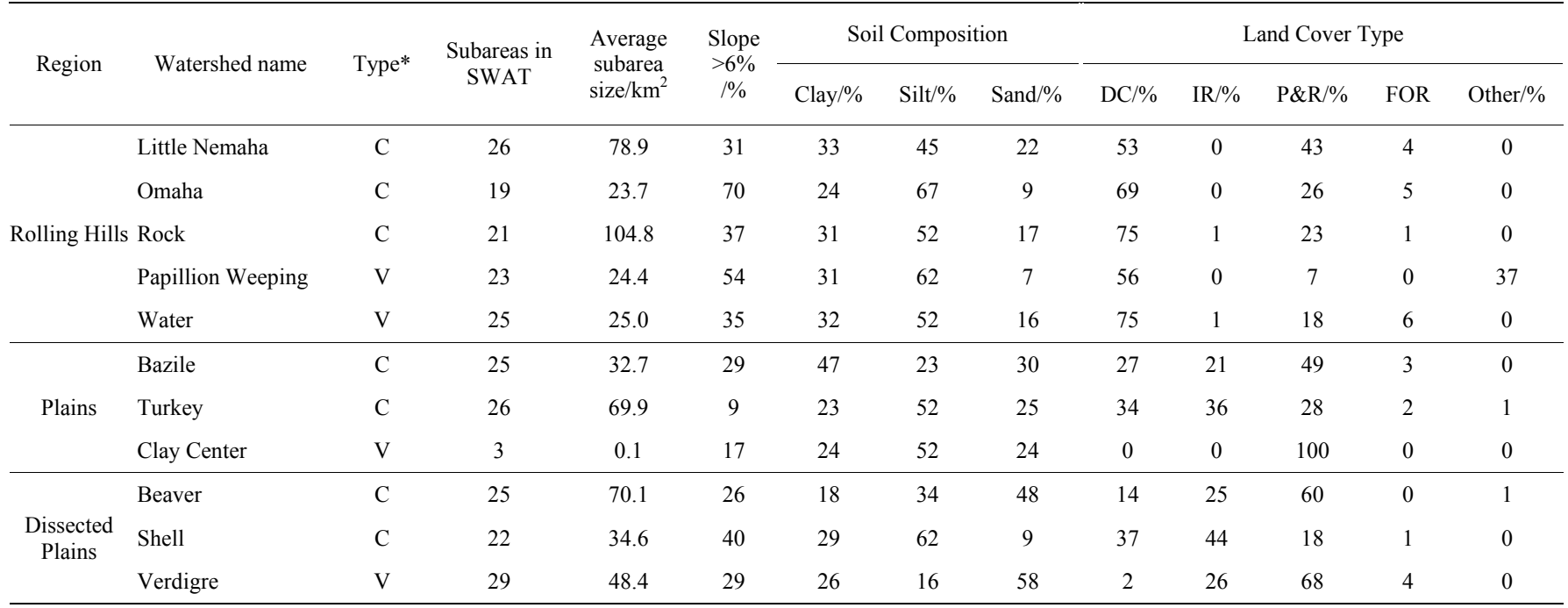

Note: Type*: $\mathrm{C}=$ calibration, $\mathrm{V}=$ Validation; Land Cover Type*: $\mathrm{DC}=$ Dryland Crop, $\mathrm{IC}=$ Irrigated Crop, $\mathrm{P} \& \mathrm{R}=\mathrm{Pasture}$ and Range, FOR=Forest.

Watersheds that were selected for this study were regionalized according to three landform types in the eastern portion of the state: Rolling Hills, Plains and Dissected Plains (Figure 1). The Rolling Hills Landform, founded on glacial till, is located near the Missouri River and rises above the flat plains. Average annual precipitation in this region ranges from about $700 \mathrm{~mm}$ in the north to $850 \mathrm{~mm}$ in the south. The Plains Landform consists of a relatively flat landscape founded on loess, while the Dissected Plains Landform consists of level to gently rolling hills that are also founded on loess. Average annual precipitation in the Plains ranges from about $640 \mathrm{~mm}$ in the north to $760 \mathrm{~mm}$ in the south, while in the Dissected Plains it ranges from about $580 \mathrm{~mm}$ in the north to $710 \mathrm{~mm}$ in the south. Among the three landforms, crop and livestock production are the dominant land use types. Based on available climate and streamflow data, five watersheds were included in the Rolling Hills Landform, while three watersheds each were included in both the Plains and Dissected Plains Landforms.

Like other ecohydrologic models, the most sensitive input variable in SWAT is precipitation. Even if the model is run in a default mode, substantial differences in the hydrologic response of the model are apparent, given differing precipitation input signals. In general, hydrologic responses due to precipitation amount and frequency tend to be much more important than responses due to variations in topographic, soils, and land cover factors as mentioned earlier. For this study, it was assumed that there were sufficient physiographic and climatic similarities among watersheds within one of the three given landforms that various approaches to regional parameterization methods could be successfully used, such that calibrated parameter data sets from calibration watersheds could be readily extended to validation watersheds within a given landform. In the Rolling Hills Landform, the Little Nemaha, Omaha, and Rock watersheds were randomly selected for model calibration and the Papillion and Weeping Water watersheds for model validation. Likewise, the Bazile and Turkey watersheds were randomly selected for model calibration and the Clay watershed for validation in the Plains Landform. In the Dissected Plains Landform, the Beaver and Shell watersheds were randomly selected for calibration and the Verdigre watershed for validation.

\subsection{Watershed delineation}

Elevation, land use, and soil characteristics were obtained from GIS data layers for the state of Nebraska. The elevation layer was developed from the USGS National Elevation Dataset (NED) at a $30 \mathrm{~m}$ resolution ${ }^{[32]}$. The land use layer was obtained from a $30 \mathrm{~m}$ resolution, 2005 land cover data set developed by the Nebraska Dept. of Natural Resources ${ }^{[33]}$. The 2005 land cover data set was chosen instead of 2011 since it better represented the years simulated. The soils layer was obtained from the USDA-NRCS STATSGO database ${ }^{[34]}$. The ArcSWAT 2012.10_2.16 interface was used to delineate each watershed into a number of subbasins and HRUs. Crop management schedules and commercial fertilizer application rates were input into the model for a corn-soybean rotation based on professional judgment and data provided by the USDA-NRCS. The auto-irrigation routine in SWAT was used for irrigating delineated cropland HRUs based on a plant cover water stress factor. A deep aquifer with an unlimited supply of water was assumed to be the source of irrigation. Although a variety of crops are grown in eastern Nebraska, corn and soybeans are the two dominant crops. Table 2 represents the management operations schedule that was used to delineate an HRU designated as a dryland corn-soybean rotation; it represents conditions that would be expected to occur under a conservation tillage operation in eastern Nebraska. Other HRU-based operation management schedules were developed and simulated for dryland soybean-corn, irrigated corn-soybean, and irrigated soybean-corn rotations.

Table 2 Conservation-tillage operation schedule for soybeans and corn

\begin{tabular}{clcc}
\hline \multirow{2}{*}{ Crop } & \multicolumn{1}{c}{ Date } & Operation & $\begin{array}{c}\text { Application rate } \\
/ \mathrm{kg} \cdot \mathrm{hm}^{-2}\end{array}$ \\
\hline \multirow{3}{*}{ Soybeans } & April 10th & $\begin{array}{c}\text { conservation tillage } \\
\text { April 20th }\end{array}$ & 1 \\
& May 1st & plant & \\
& September 30th & harvest and kill & \\
\hline \multirow{6}{*}{ Corn } & April 10th & conservation tillage & \\
& April 20th & pesticide application & 1 \\
& May 1st & 18-46-00 fertilizer & 150 \\
& May 15th & plant & \\
& September 30th & harvest and kill & 150 \\
& October 25th & anhydrous ammonia & \\
\hline
\end{tabular}

Observed climatic and streamflow records were used to calibrate parameters that govern hydrologic processes in SWAT. Precipitation and air temperature data were obtained from the High 
Plains Regional Climate Center for climate stations either within or near a given watershed (Figure 1). Streamflow data for the selected watersheds were obtained from USGS gaging stations that corresponded with available climatic data. For this study, the precipitation streamflow response for most watersheds was calibrated using a single weather station and a single streamflow gage for a given watershed. For Papillion and Turkey, the precipitation streamflow calibration response was based on two precipitation gages.

\subsection{Calibration parameters}

Before assessments were made to evaluate the three approaches that were used for model parameterization, each of the eleven watersheds was calibrated independently. A total of ten calibration parameters that govern precipitation runoff processes in SWAT were calibrated on each of the watersheds. As shown in Table 3, the ten SWAT parameters were grouped into four categories, which were assumed to predominantly govern basin, surface, ground water, and reach response, respectively. Parameters chosen for calibration included one basin parameter (SURLAG), three surface parameters (ESCO, EPCO, and SOL_AWC), four ground water parameters (ALPHA_BF, GWQMN, RCHRG_DP, GW_DELAY) and two reach parameters $\left(\mathrm{CH} \_\mathrm{N} 2, \mathrm{CH} \_\mathrm{K} 2\right)$.

Table 3 Parameters calibrated in SWAT, their name, lower and upper limits, and default values

\begin{tabular}{|c|c|c|c|c|c|c|}
\hline Category & Parameter & Description & Units & $\begin{array}{l}\text { Lower } \\
\text { Limit }\end{array}$ & $\begin{array}{l}\text { Upper } \\
\text { Limit }\end{array}$ & $\begin{array}{c}\text { Default } \\
\text { Value }\end{array}$ \\
\hline Basin & SURLAG & surface runoff lag time & d & 0.5 & 12 & 4 \\
\hline Surface & ESCO & soil evaporation compensation factor & none & 0.05 & 1 & 0.95 \\
\hline Surface & EPCO & plant uptake compensation factor & none & 0.05 & 1 & 1 \\
\hline Surface & SOL_AWC & available soil water capacity for plants & $\mathrm{mm} / \mathrm{mm}$ & -0.4 & 0.4 & 0 \\
\hline Subsurface & ALPHA_BF & baseflow alpha factor, or recession constant & d & 0 & 1 & 0.048 \\
\hline Subsurface & GWQMN & threshold depth of water in the shallow aquifer required for return flow to occur & $\mathrm{mm}$ & 0 & 5000 & 0 \\
\hline Subsurface & RCHRG_DP & deep recharge percolation fraction & none & 0.01 & 1 & 0.05 \\
\hline Subsurface & GW_DELAY & time for water to leave the bottom of the root zone and reach the shallow aquifer & d & 1 & 500 & 31 \\
\hline Reach & CH_N2 & channel Manning's n & none & 0.01 & 0.06 & 0.014 \\
\hline Reach & CH_K2 & channel hydraulic conductivity & $\mathrm{mm} / \mathrm{h}$ & 0 & 150 & 1 \\
\hline
\end{tabular}

\subsection{Model evaluation criteria}

For model simulations in a given investigation to be relevant and defensible, there must be a means by which simulated model output can be evaluated against measured data. Moriasi et al. ${ }^{[35]}$ point out that previous research has produced valuable comparative information on selected model evaluation techniques, but no comprehensive standardization is available that includes recently developed statistics with corresponding performance ratings and applicable guidelines for model evaluation. They developed a set of guidelines for model evaluation that were based on a comprehensive review of model simulation results and project specific considerations. Two evaluation criteria recommended from their study were used in this study to assess monthly streamflow simulated by SWAT. These two criteria were quantitative statistics that measured the agreement between simulated and observed values. In the first criterion, percent bias (PBIAS) represents a measure of the average tendency of the simulated output to be larger or smaller than their observed values. A positive value of PBIAS indicates a model bias toward underestimation, while a negative value indicates a model bias toward overestimation; $0.0 \%$ represents the optimal value of PBIAS. $^{[36]}$ The second criterion used in this study is the Nash Sutcliffe coefficient of efficiency (NSE) ${ }^{[37]}$, which Servat and Dezetter ${ }^{[38]}$ found to be the best objective function for reflecting the overall fit of a hydrograph. NSE expresses the fraction of the measured streamflow variance that is reproduced by the model.

Based on values of the two test statistics NSE and PBIAS, qualitative performance ratings were determined for the streamflow output obtained in this study. For a performance rating to at least be considered satisfactory, the NSE value had to be greater than or equal to 0.50 , while PBIAS had to be less than or equal to $\pm 25 \%$. "Good" and "very good" performance ratings for streamflow as based upon the two test statistics used in this study are shown in Table $4^{[34]}$.
Table 4 Performance ratings for streamflow for the test statistics used in this study ${ }^{[33]}$

\begin{tabular}{ccc}
\hline Performance rating & NSE & PBIAS (\%) streamflow \\
\hline Very Good & $0.75<\mathrm{NSE} \leq 1.0$ & PBIAS $< \pm 10$ \\
Good & $0.65<\mathrm{NSE} \leq 0.75$ & $\pm 10 \leq$ PBIAS $< \pm 15$ \\
Satisfactory & $0.50<\mathrm{NSE} \leq 0.65$ & $\pm 15 \leq$ PBIAS $< \pm 25$ \\
Unsatisfactory & $\mathrm{NSE} \leq 0.50$ & PBIAS $\geq \pm 25$ \\
\hline
\end{tabular}

\subsection{Default simulations and model calibration}

The procedural steps that were taken to perform this regionalization study are outlined in Appendix A. A brief summary of these steps is as follows. First of all, calibration and validation watersheds were chosen within each of the respective landforms of the study area. Second, model simulations were performed using the default parameter settings in SWAT. Third, parameters in the model were calibrated for each of the calibration and validation watersheds. Next, the regional average, nearest neighbor, and donor methods were used within each of the respective landforms. Finally, simulations results from the default, calibration, and regionalization methods were compared to identify the various strengths and weaknesses of each method.

The default and calibrated simulations that were conducted in this study were used to define the potential range in model performance that would be expected to occur with and without model calibration. Parameter settings for simulations performed in the default mode are listed in Table 5. The default simulation represents the watershed response that would be expected to occur if no data were available for estimating hydrologic parameters in the model.

All watersheds used in the study, whether classified as calibration or validation, were calibrated at a monthly time scale to define the best possible response that would be expected to occur given the available input data for each project. Model calibration in this study involved a three-step process, whereby watersheds were 
calibrated independently of each other. In the first step, model simulations were performed using the default settings as a check on water balance and as an initial comparison against measured data. In the second step, the autocalibration tool SWAT-CUP was used to calibrate streamflow ${ }^{[39]}$. The SUFI-2 optimization scheme was used in SWAT-CUP to perform the autocalibration using the NSE as the objective function. This approach tended to maximize the value of NSE but lower the value of PBIAS. In the third step, manual adjustments were made to a handful of parameters in order to achieve satisfactory values of PBIAS while maintaining the highest possible values of NSE. Each of the eleven test watersheds were calibrated to obtain the best possible combination of PBIAS and NSE values prior to performing model simulations that were used to compare the results of the regional parameterization methodologies.

Table 5 Parameters values calibrated for the eleven watersheds

\begin{tabular}{|c|c|c|c|c|c|c|c|c|c|c|c|c|c|c|c|}
\hline Category & Parameter & Lower limit & $\begin{array}{l}\text { Upper } \\
\text { limit }\end{array}$ & $\begin{array}{c}\text { Default } \\
\text { value }\end{array}$ & Bazile & Beaver & $\begin{array}{l}\text { Clay } \\
\text { center }\end{array}$ & $\begin{array}{c}\text { Little } \\
\text { nemaha }\end{array}$ & Omaha & Papillion & Rock & Shell & Turkey & Verdigre & $\begin{array}{c}\text { Weeping } \\
\text { water }\end{array}$ \\
\hline Basin & SURLAG & 0.5 & 12 & 4 & 1.61 & 3.83 & 9.53 & 3.35 & 7.76 & 9.53 & 5.73 & 1.93 & 3 & 0.58 & 9.41 \\
\hline Surface & EPCO & 0.05 & 1 & 1 & 0.414 & 0.66 & 0.478 & 0.58 & 0.1 & 0.858 & 0.65 & 0.87 & 0.991 & 0.9 & 0.7 \\
\hline Surface & SOL_AWC & -0.4 & 0.4 & 0 & 0.4 & 0 & 0 & 0.33 & 0 & 0.32 & 0 & 0 & 0 & 0.4 & 0 \\
\hline Subsurface & ALPHA_BF & 0 & 1 & 0.048 & 0.15 & 0.75 & 0.65 & 0.567 & 0.878 & 0.05 & 0.83 & 0.95 & 0.966 & 0.15 & 0.05 \\
\hline Subsurface & GWQMN & 0 & 5000 & 0 & 1750 & 4250 & 0 & 4833 & 0 & 0 & 2650 & 0 & 501 & 0 & 417 \\
\hline Subsurface & RCHRG_DP & 0.01 & 1 & 0.05 & 0.757 & 0.265 & 0.055 & 0.5753 & 0.01 & 0.12 & 0.1474 & 0.01 & 0.3043 & 0.953 & 0.9842 \\
\hline Subsurface & GW_DELAY & 1 & 500 & 31 & 275 & 93 & 177 & 44 & 460 & 1 & 311 & 387 & 252 & 135 & 289 \\
\hline Reach & CH_N2 & 0.01 & 0.06 & 0.014 & 0.0525 & 0.0275 & 0.0575 & 0.0417 & 0.0595 & 0.0492 & 0.0475 & 0.0325 & 0.0475 & 0.0375 & 0.0492 \\
\hline Reach & CH_K2 & 0 & 150 & 1 & 92.5 & 127.5 & 67.5 & 45 & 1 & 27.5 & 142.5 & 7.5 & 72.5 & 37.5 & 27.5 \\
\hline
\end{tabular}

\subsection{Comparison of regional parameterization methodologies}

For this study, three methods were used to regionalize parameters in SWAT. The first method was referred to as a regional averaging approach. In this method, the model parameters from the three calibration watersheds within the Rolling Hills Landform were averaged and then applied for model simulations on each of the three calibrated and two validated watersheds in that region. The same procedure was used for watersheds in the Plains and Dissecting Plans Landforms.

The second regionalization method, referred to as nearest neighbor, was based on the spatial proximity (or spatial distance) between the calibrated or validated watershed of interest and the calibrated watersheds within a given landform. This method implicitly assumed the existence of similarities among watersheds because of their location relative to one another within a particular region. Spatial proximity between two watersheds was manually estimated in the GIS display as the measured distance between the respective watershed centroids. For the Rolling Hills Landform, the complete set of model parameters was taken from one of the three calibration watersheds and applied to a recipient, calibration or validation watershed within that region. The same approach was implemented for the other two landforms.

The third regionalization method used in this study was based on watershed attributes, instead of spatial proximity between two watersheds. The main idea of this method was to find a donor watershed that was most similar in terms of its watershed attributes, and to transpose the complete parameter set to the calibrated or validated watershed of interest within a given landform ${ }^{[12]}$. The donor watershed was selected as the calibrated watershed within a given region with the smallest similarity index $D$ (e.g. Burn and Boorman $)^{[8] \text { : }}$

$$
D=\sum_{i=0}^{k}\left|X_{i}^{G}-X_{i}^{U}\right| / D X_{i}
$$

which is defined as the sum of absolute differences of the $k$ selected physiographic attributes of the calibrated $X_{i}^{G}$ watershed and the calibration or validation watershed of interest $\left(X_{i}^{U}\right)$, normalized by its range $D X_{i}{ }^{[8]}$ where $i$ is a given physiographic attribute. Six attributes used in this study included average annual precipitation and percentages of: sand present in the soil, slopes greater than $6 \%$, land cover designated as range/pasture, dryland agriculture, and irrigated agriculture.

\section{Results}

\section{1 Default and calibrated simulations}

Results of the default and calibration simulations were evaluated based on the monthly values of PBIAS and NSE. These test statistics as well as a performance criterion based upon suggested guidelines by Moriasi et al. ${ }^{[35]}$ are presented in Table 6 for the default and calibrated simulations. Test results show under the default simulation, Rock (good) and Turkey (satisfactory) were the only sites that were considered to have at least a satisfactory or better rating among the eleven test watersheds. Examination of the default simulations shows that the median PBIAS and NSE values for the eleven watersheds were $-54.2 \%$ and -0.86 , respectively, with PBIAS ranging from $-148 \%$ (Clay) to $45.8 \%$ (Omaha) and NSE ranging from -5.69 (Bazile) to 0.69 (Rock). These NSE values are similar to those reported in the literature for streamflow simulations performed with SWAT under the default mode. For example, Van Liew and Garbrecht ${ }^{[40]}$ reported NSE values ranging from -4.49 to -1.88 for default parameters in SWAT on two subwatersheds of the Little Washita Experimental Watershed in Oklahoma during a period of record from 1992 to 2000. Under the default mode, Gitau and Chaubey ${ }^{[13]}$ reported NSE values ranging from -1.96 to 0.61 for five watersheds in Arkansas that they simulated with SWAT from 1998 to 2000.

Based on NSE calibration results, five of the eleven watersheds were considered very good, four were good and three satisfactory. Under the calibration mode, many of the calibrated parameters exhibited nearly the entire suggested parameter range (Table 5). Calibrated parameters displaying these wide ranges included EPCO (0.1 [Omaha] to 0.991 [Turkey]), DELAY (1 [Papillion] to 460 [Omaha]), RCHRG_DP (0.01 [Omaha] to 0.0 [Rock] $)$, and CH_K2 (1 [Omaha] to 143 [Rock]). Results of the model simulations on all eleven watersheds that were calibrated independently of one another show that PBIAS ranged from $-13.9 \%$ (Papillion) to $16.6 \%$ (Beaver) while NSE ranged from 0.51 (Verdigre) to 0.84 (Weeping Willow) (Table 6). Median PBIAS and NSE values for the eleven watersheds were $6.0 \%$ and 0.72 , respectively. For 
watersheds within the Rolling Hills Landform, the average NSE was 0.75 . These values were similar to those reported in the Plains Landform, where the average NSE was 0.78. Model performance among the watersheds in the Dissected Plains Landform was weaker relative to the other two regions, with an average NSE 0.59 . These results are similar to findings by Van Liew et al. ${ }^{[41]}$ who reported that SWAT tends to perform better in wetter than dryer climatic regimes. Based on the qualitative performance ratings developed by Moriasi et al., ${ }^{[35]}$ simulated streamflow at the monthly time scale for the three watersheds within the Dissected Plains Landform was considered to be good for Shell and satisfactory for Beaver and Verdigre.

Table 6 Average annual measured precipitation $(\mathrm{mm})$, measured and simulated streamflow $(\mathrm{mm})$, and test statistics and performance criterion for the default, calibrated, and regionalization model simulations

\begin{tabular}{|c|c|c|c|c|c|c|c|c|c|c|c|c|}
\hline & Name & $\begin{array}{c}\text { Little } \\
\text { Nemaha }\end{array}$ & Omaha & Rock & Papillion & $\begin{array}{l}\text { Weeping } \\
\text { Water }\end{array}$ & Bazile & Turkey & Clay Center & Beaver & Shell & Verdigre \\
\hline & Start of Period & Jan.'06 to & Jan.'99 to & Jan.'13 to & Oct.'06 to & Jan.'08 to & Jan.'09 to & Jan.'07 to & Sept.'76 to & Sept.'07 to & Jan.'98 to & Jan.'08 to \\
\hline Simulation & End of Period & Dec.'09 & Dec.'00 & Dec.'15 & Sept.'07 & May'10 & Dec.'10 & Sept.'08 & May'78 & Dec.'09 & Dec.'00 & Dec.'09 \\
\hline \multirow[t]{3}{*}{ Mode } & Watershed Type* & $\mathrm{C}$ & $\mathrm{C}$ & $\mathrm{C}$ & V & V & $\mathrm{C}$ & $\mathrm{C}$ & $\mathrm{V}$ & $\mathrm{C}$ & $\mathrm{C}$ & $\mathrm{V}$ \\
\hline & Meas. Precip. & 870 & 677 & 903 & 868 & 912 & 787 & 819 & 763 & 713 & 679 & 666 \\
\hline & Meas. flow & 201 & 151 & 142 & 97 & 222 & 122 & 138 & 78 & 93 & 78 & 119 \\
\hline \multirow{4}{*}{ Default } & Sim. Streamflow & 346 & 81.8 & 122 & 239 & 296 & 188 & 131 & 193 & 169 & 121 & 116 \\
\hline & PBIAS** & -72.1 & 45.8 & 13.9 & -146 & -33.3 & -54.2 & 5.4 & -148 & -81.3 & -54.5 & 2.4 \\
\hline & NSE*** & 0.29 & 0.64 & 0.69 & -3.33 & 0.58 & -5.69 & 0.63 & -1.06 & -5.51 & -0.86 & -2.25 \\
\hline & Performance $* * * *$ & $\mathrm{U}$ & $\mathrm{U}$ & G & $\mathrm{U}$ & $\mathrm{U}$ & $\mathrm{U}$ & $\mathrm{S}$ & $\mathrm{U}$ & $\mathrm{U}$ & $\mathrm{U}$ & $\mathrm{U}$ \\
\hline \multirow{4}{*}{ Calibrated } & Sim. Streamflow & 218 & 138 & 133 & 110 & 230 & 105 & 150 & 78 & 78 & 68 & 109 \\
\hline & PBIAS & -8.3 & 8.7 & 6 & -13.9 & -3.5 & 13.6 & -9 & 0 & 16.6 & 13 & 8.7 \\
\hline & NSE & 0.8 & 0.75 & 0.67 & 0.71 & 0.84 & 0.7 & 0.83 & 0.8 & 0.57 & 0.69 & 0.51 \\
\hline & Performance & VG & VG & G & $\mathrm{G}$ & VG & G & VG & VG & S & G & S \\
\hline \multirow{4}{*}{$\begin{array}{l}\text { Regional } \\
\text { Average }\end{array}$} & Sim. Streamflow & 250 & 47 & 73 & 203 & 214 & 143 & 53 & 89 & 65 & 62 & 59 \\
\hline & PBIAS & -24.3 & 68.9 & 48.9 & -109 & 3.5 & -17.5 & 61.9 & -14.6 & 29.9 & 20.1 & 50.4 \\
\hline & NSE & 0.73 & 0.27 & 0.4 & -1.74 & 0.82 & -3.43 & 0.19 & 0.79 & 0.57 & 0.71 & -0.23 \\
\hline & Performance & $\mathrm{S}$ & $\mathrm{U}$ & $\mathrm{U}$ & $\mathrm{U}$ & VG & $\mathrm{U}$ & $\mathrm{U}$ & G & $\mathrm{U}$ & $\mathrm{S}$ & U \\
\hline \multirow{4}{*}{$\begin{array}{l}\text { Nearest } \\
\text { Neighbor }\end{array}$} & Sim. Streamflow & 273 & 81 & 18 & 226 & 86 & 223 & 42 & 183 & 151 & 49 & 80 \\
\hline & PBIAS & -35.6 & 46.2 & 87 & -133 & 61.4 & -82.9 & 69.4 & -134 & -62.5 & 37.8 & 32.8 \\
\hline & NSE & 0.69 & 0.61 & -0.26 & -2.9 & 0.4 & -5.1 & -0.07 & -0.21 & -0.39 & 0.76 & 0.3 \\
\hline & Performance & $\mathrm{U}$ & $\mathrm{U}$ & $\mathrm{U}$ & $\mathrm{U}$ & $\mathrm{U}$ & $\mathrm{U}$ & $\mathrm{U}$ & $\mathrm{U}$ & $\mathrm{U}$ & $\mathrm{U}$ & $\mathrm{U}$ \\
\hline \multirow{4}{*}{ Donor } & Sim. Streamflow & 273 & 81 & 18 & 226 & 226 & 223 & 42 & 1 & 151 & 49 & 80 \\
\hline & PBIAS & -35.6 & 46.2 & 87 & -133 & -2 & -82.9 & 69.4 & 99.2 & -62.5 & 37.8 & 32.8 \\
\hline & NSE & 0.69 & 0.61 & -0.26 & -2.9 & 0.83 & -5.1 & -0.07 & -0.33 & -0.39 & 0.76 & 0.3 \\
\hline & Performance & $\mathrm{U}$ & $\mathrm{U}$ & $\mathrm{U}$ & $\mathrm{U}$ & VG & $\mathrm{U}$ & $\mathrm{U}$ & $\mathrm{U}$ & $\mathrm{U}$ & $\mathrm{U}$ & $\mathrm{U}$ \\
\hline
\end{tabular}

Note: Watershed Type*: $\mathrm{C}=$ calibration, $\mathrm{V}=$ validation; PBIAS** $=$ Percent Bias; NSE*** = Nash Sutcliffe Coef. of Efficiency; Performance**** : U = unsatisfactory, $\mathrm{S}=$ satisfactory, $\mathrm{G}=$ good, $\mathrm{VG}=$ very good.

Computed values of NSE as shown in Table 6 suggest that in most cases, SWAT accurately replicated monthly variations in the observed streamflow. This is further illustrated in the comparison of monthly measured, default, and calibrated streamflow in Figure 2 for the Bazile, Weeping Water Clay Center, and Omaha Watersheds. For these four watersheds, calibrated results were considered good, very good, very good and very good, respectively. Discrepancies between measured versus simulated responses were largely attributed to data deficiencies in the spatial and temporal representation of precipitation on many of the respective watersheds.

\subsection{Comparison of regional parameterization methods}

A comparison of performance evaluation for the regional average, nearest neighbor, and donor methods used in this study is presented in Table 6 for the seven calibration and four validation watersheds. Based upon the performance criterion, only two of the calibration (Little Nemaha and Shell) and two of the validation watersheds (Weeping Water and Clay) were considered satisfactory or better using the regional average regionalization method. Values of PBIAS and NSE ranged from $-24.3 \%$ to $68.9 \%$ and -3.43 to 0.73 , respectively, for all calibration watersheds and $-109 \%$ to $50.4 \%$ and -1.74 to 0.82 for all validation watersheds. For the
Rolling Hills, Plains, and Dissected Plains Landforms, the average NSE for both calibration and validation watersheds were 0.10 , -0.81 and 0.35 , respectively.

For the nearest neighbor approach, none of the eleven test watersheds were considered satisfactory. For all calibration watersheds, PBIAS and NSE ranged from $-82.9 \%$ to $87.0 \%$ and -5.1 to 0.76 , respectively, and $-134 \%$ to $61.4 \%$ and -2.9 to 0.40 for all validation watersheds. Average NSE values for both calibration and validation watersheds were $-0.29,-1.79$, and 0.22 , for the Rolling Hills, Plains, and Dissected Plains Landforms, respectively.

Using the donor method, performance of the model was considered very good for the Weeping Water watershed, but the other ten watersheds were considered unsatisfactory. With the exception of the Weeping Water and Clay Center watersheds, reported values of PBIAS and NSE using the donor method were identical to the nearest neighbor values. This is because the selective pool of calibration watersheds in each of the three landforms was very small-only three in the Rolling Hills Landform and only two in each of the Plains and Dissected Plains Landforms. It was just by coincidence that four out of the five 
watersheds of interest had the same nearest neighbor and donor watersheds within the Rolling Hills Landform. The same could be said for the Dissected Plains Landform, where each of the three watersheds of interest had identical nearest neighbor and donor
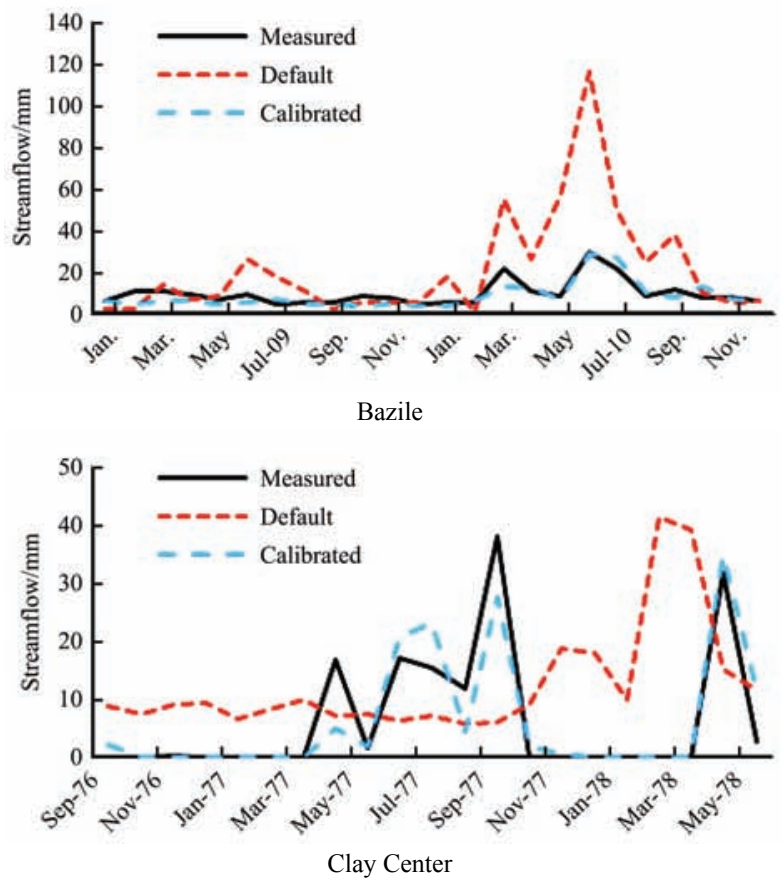

Clay Center

\section{Discussion}

Findings from this study indicate that only two out of the eleven test watersheds gave at least satisfactory results for simulating streamflow under a default mode. Since SWAT did not perform well in simulating streamflow when using the default approach, it is recommended that use of the model in this mode be limited to situations such as relative comparisons due to climate or land use change. When each of the eleven watersheds was calibrated independently of one another, results show that model performance was considered satisfactory for two, good for four, and very good for five of the project watersheds. This marked improvement in model performance compared to simulations under the default mode emphasizes the importance of model calibration. This outcome is also consistent with previous summaries of SWAT streamflow statistical results across multiple studies, which revealed that the majority of computed monthly (and daily) statistics satisfied suggested criteria for satisfactorily replicating corresponding observed streamflows ${ }^{[42,43]}$.

Test results from this study were compared to results from two previous studies (Gitau and Chaubey ${ }^{[13]}$ and Parajka et al. ${ }^{[12]}$ For the present study, median NSE values for monthly streamflow using the regional average approach were 0.40 and 0.28 for the source and validation watersheds, respectively. The median NSE value for monthly streamflow was 0.69 for calibrated watersheds used in the study by Gitau and Chaubey, ${ }^{[13]}$ while the median daily streamflow NSE values for calibrated and validated values were 0.61 and 0.56 in the study performed by Parajka et al. ${ }^{[12]}$ In the comparison of the nearest neighbor approach in this study, median monthly NSE values were -0.07 and 0.05 for the source and validated watersheds, respectively, while Parajka et al. ${ }^{[12]}$ reported median daily NSE values of 0.66 and 0.61 , respectively. Results obtained from the donor approach used in this study show watersheds. Average NSE values were -0.54 for all calibration watersheds and -0.53 for all validation watersheds. For the Dissected Plains, Plains, and Rolling Hills Landforms, the average NSE values were $-0.21,-1.83$ and 0.22 , respectively.
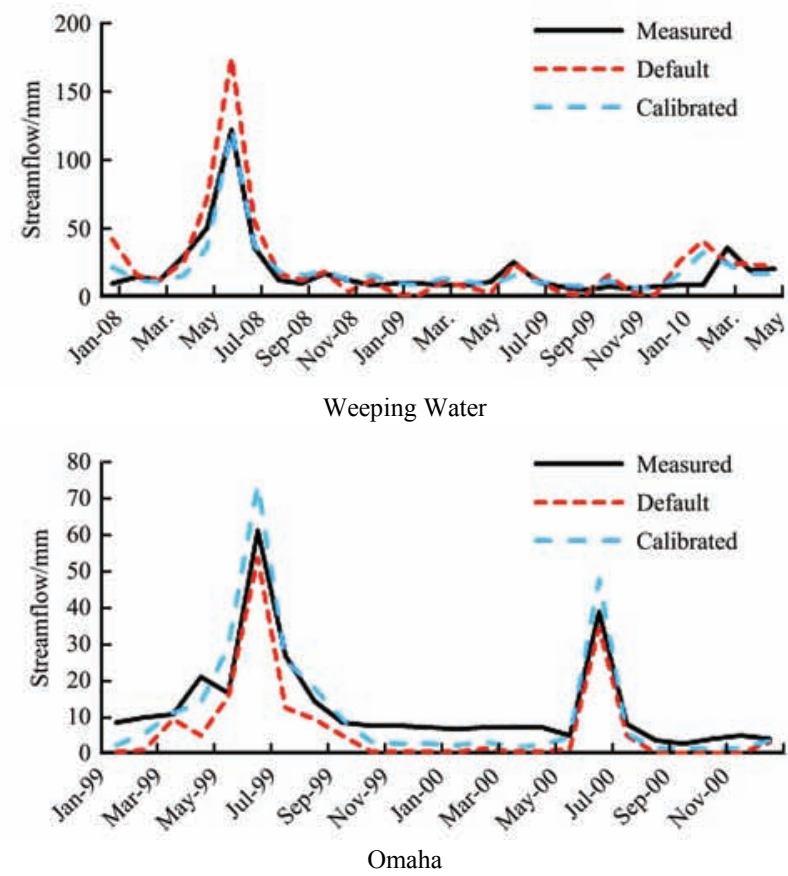

Omaha median daily NSE values of 0.67 and 0.61 obtained by Parajka et al., ${ }^{[12]}$ respectively. These comparisons for the three regionalization approaches used in this study show that the median values were considered unsatisfactory for both the calibration and validation watersheds, and compared poorly with the results obtained by Gitau and Chaubey ${ }^{[13]}$ and Parajka et al. ${ }^{[12]}$

It may be said that none of the three approaches used in this investigation gave even marginally satisfactory results, based on both the NSE and PBIAS test statistics. Of the three methods, only two calibration and two validation watersheds were considered satisfactory for the regional average approach, none was considered satisfactory for the nearest neighbor approach, and only one calibration watershed was considered satisfactory for the donor approach. Findings from this study therefore suggest that none of these methods when applied across the eastern Nebraska landscape will provide sufficient parameter value information to perform satisfactory simulations on ungaged watersheds in the region at the monthly time scale.

Each of the three regionalization methods used in this investigation used a distinct approach in estimating a model parameter set for streamflow simulation. In the regional average approach, it is assumed that the average values of the given parameters taken from the available calibrated data sets will adequately represent hydrologic conditions simulated by the model within a given region. Results of this study show that average values can be readily computed, and applied to other watersheds of interest with four of the eleven studied watersheds having a satisfactory rating. In the nearest neighbor approach, the assumption is made that there are enough similarities between a watershed of interest and a nearby calibrated watershed that the parameter set from the latter watershed will provide sufficient information for suitable model simulations. Although distances 
among watersheds within a given landform region could be readily determined in this study, performance of this approach was considered unsatisfactory. In the donor approach used in this study, six climatic and physiographic attributes were used to identify a donor watershed that was most similar to a particular watershed of interest. The computational time required for performing these computations was somewhat more than that needed for the other two methods. Unfortunately, this method yielded poor results, with only one of the eleven studied watersheds having a satisfactory rating.

Among the eleven test watersheds Weeping Water, followed by Clay Center, exhibited the best model performances among the watersheds when applied to the regionalization methods. As noted in Table 5, the model performance for each of these watersheds was considered very good under the calibration mode. Although difficult to substantiate from the limited findings obtained from this study, test results suggest that watersheds that can be calibrated very well are more likely to exhibit a better performance rating when applied to one of the regionalization approaches, while those watersheds whose calibration is only marginal are more likely to exhibit an unsatisfactory performance rating under regional parameterization. The implication of this finding is that the degree of success in the model parameterization of a particular landscape is highly dependent upon the capability of achieving suitable calibrations that can be used in the regionalization process.

Many limitations were encountered in this study in developing a satisfactory set of watershed projects throughout the eastern third of the State of Nebraska that could be used to test the various regionalization methods proposed for model calibration. Due to unforeseen difficulties in project delineation or inadequate precipitation-runoff data, it was not possible to include as many watersheds among the three landform regions as was originally planned. The use of a higher resolution DEM than the one selected in the study might have led to additional delineations that could have been included in the study. Moreover, the use of improved methods for spatial and temporal estimation of precipitation across a given watershed could have improved streamflow simulations with SWAT. It is also possible that a higher resolution management schedule that better defined spatial and temporal variations in field operations could have provided the needed detail to better characterize hydrologic processes for additional watersheds in the project area. Only those watersheds that could be calibrated to achieve at least a satisfactory performance based upon the criteria presented by Moriasi et al. ${ }^{[35]}$ were used in the project. The very limited number of watersheds that could be satisfactorily calibrated among the three landform regions was likely the most important factor that limited the successful implementation of the three regionalization approaches used in this investigation. A wider selection of watersheds with varying topographic, soils, and land cover conditions would have most likely improved the available choices from which to select a suitable parameter set for a watershed of interest within a given landform region.

\section{Conclusions}

In this study, three approaches to regionalization of parameters in the SWAT model were compared using eleven watersheds located in three landform regions of the eastern portion of Nebraska, United States. These three approaches included regional averaging, nearest neighbor, and donor analysis methods that have commonly been used in previous investigations. Following the delineation of eleven SWAT projects that were created in Nebraska, streamflow simulations were performed using default and calibrated parameter sets. Based on the percent bias (PBIAS) and Nash Sutcliffe Coefficient of Efficiency (NSE) test statistics, only two of the eleven watersheds were considered satisfactory or better under the default mode. This finding suggests that use of the model in this mode for addressing water resource issues be exercised on a limited basis, such as relative comparisons due to land or climate change. When calibrated, the performance rating ${ }^{[35]}$ for simulating streamflow based on the test statistics was considered very good for five, good for four, and satisfactory for two of the watersheds.

Of the three regionalization methods implemented in this study, the regional average approach gave better results than the nearest neighbor or donor approaches, but all three approaches were considered unsatisfactory. Findings from this study indicate that implementing any one of these three methods across the eastern Nebraska landscape would not provide sufficient parameter value information to perform satisfactory simulations on ungaged watersheds in the region. The very limited number of watersheds that could be satisfactorily calibrated among the three landform regions was likely the most important factor that limited the successful implementation of the three regionalization approaches used in this investigation. Improved methods for representing precipitation in SWAT are needed to provide a wider selection of watersheds that can be used to increase the number of available choices for selecting a suitable parameter set for a watershed of interest within a particular landform region.

\section{[References]}

[1] Borah D K Bera M. Watershed-scale hydrologic and nonpoint-source pollution models: review of mathematical bases. Trans ASABE, 2003; 46(6): 1553-1566. doi: 10.13031/2013.15644.

[2] Borah, D K, Yagow G, Saleh A, Barnes P L, Rosenthal W, Krug E C et al. Sediment and nutrient modeling for TMDL development and implementation. Trans ASABE, 2006; 49(4): 967-986. doi: 10.13031/2013.21742.

[3] Mottes, C., Lesueur-Jannoyer M, Le Bail M, Malezieux E. Pesticide transfer models in crop and watershed systems: a review. Agron Sustain Develop, 2014; 34(1): 229-250. doi: 10.1007/s13593-013-0176-3.

[4] Radcliffe, D E, Freer J, Schoumans O. Diffuse phosphorus models in the United States and Europe: Their usages, scales, and uncertainties. J Environ Qual, 2009; 38: 1956-1967. doi: 10.2134/jeq2008.0060.

[5] Bloschl G, Sivapalan M. Scale issues in hydrological modeling: A review. Hydrol Process, 1995; 9: 251-290. doi: 10.1002/hyp.3360090305.

[6] Vandewiele G L, Elias A. Monthly water balance of ungauged catchments obtained by geographical regionalization. J Hydrol, 1995; 170: 277-291. doi: 10.1016/0022-1694(95)02681-E.

[7] Merz R, Bloschl G. Regionalisation of catchment model parameters. JHydrol, 2004; 287: 95-123. doi: j.jhydrol.2003.09.028.

[8] Burn D H, Boorman D B. Estimation of hydrological parameters at ungauged catchments. J Hydrol, 1993; 143: 429-454. doi: 10.1016/0022-1694(93)90203-L

[9] Fernandez W, Vogel R M, Sankarasubramanian A. Regional calibration of a watershed model. Hydrol Sci J, 2000; 45(5): 689-707. doi: $10.1080 / 02626660009492371$.

[10] Heuvelmans G, Muys B, Feyen J. Regionalisation of the parameters of a hydrological model: Comparison of linear regression models with artificial neural nets. J Hydrol, 2006; 319(1-4): 245-265. doi: 10.1016/ j.jhydrol.2005.07.030.

[11] Sellami H, La Jeunesse I, Benabdallah S, Baghdadi N, Vanclooster M. Uncertainty analysis in model parameters regionalization: a case study involving the SWAT model in Mediterranean catchments (Southern France). Hydrol Earth Syst Sci, 2014; 18: 2393-2413. doi: 10.5194/hess-18-2393-2014. 
[12] Parajka J R, Merz G, Bioschi G. A comparison of regionalization methods for catchment model parameters. Hydrol Earth Syst Sci, 2005; 2: 509-542. doi: 10.5194/hess-9-157-2005.

[13] Gitau M W, Chaubey I. Regionalization of SWAT model parameters for use in ungaged watersheds. Water, 2010; 2: 849-871. doi: 10.3390/w2040849

[14] Pagliero L, Bouraoui F, Willems P, Diels J. Large scale hydrological simulations using SWAT, protocol development and application in the Danube Basin. J Environ Qual, 2014; 43(1): 145-154. doi: 10.2134/jeq2011.0359.

[15] Daggupati P, Deb D, Srinivasan R, Yeganantham D, Mehta V M, Rosenberg N J. Large-scale fine-resolution hydrological modeling using parameter regionalization in the Missouri River Basin. J Amer Water Resour Assoc, 2016; 52(3): 648-666. doi: 10.1111/1752-1688.12413.

[16] Swain J B, Patra K C. Streamflow estimation in ungauged catchments using regionalization techniques. J Hydrol, 2017; 554: 420-433. doi: 10.1016/j.jhydrol.2017.08.054.

[17] Chen X, Chen X. Simulating the effects of reduced precipitation on ground water and streamflow in the Nebraska Sand Hills. Journal of the American Water Resources Association, 2004; 40: 419-430. doi: 10.1111/j.1752-1688.2004.tb01040.x.

[18] Daggupati P, Deb D, Srinivason R, Yeganantham D, Mehta V M,Rosenberg N J. Large-scale fine-resolution hydrological modeling using parameter regionalization in the Missouri River basin. $\mathrm{J}$ Amer Water Resour Assoc, 2016; 52(3): 648-666. doi: 10.1111/ 1752-1688.12413.

[19] Woznicki S A, Nejadhashemi A P, Smith C M. Assessing best management practice implementation strategies under climate change scenarios. Trans ASABE, 2011; 54(1): 171-190. doi: 10.13031/2013.36272.

[20] Van Liew M W, Feng S, Pathak T B. Climate change impacts on streamflow, water quality, and best management practices for the Shell and Logan Creek Watersheds in Nebraska, USA. Int J Agric \& Biol Eng, 2012; 5(1): 13-34. doi: 10.3965/j.ijabe.20120501.003.

[21] Arnold J G, Srinivasan R, Muttiah R S, Williams J R. Large area hydrologic modeling and assessment part I: Model development. J Amer Water Resour Assoc, 1998; 34(1): 73-89. doi: 10.1111/j.17521688.1998.tb05961.x

[22] Bieger K, Arnold J G, Rathjens H, White M J, Bosch D D, Allen P M, et al. Introduction to SWAT+, a completely restructured version of the soil and water assessment tool. J Amer Water Resour Assoc, 2016; 53(1): 115-130. doi: 10.1111/1752-1688.12482.

[23] Gassman P W, Reyes M R, Green C H, Arnold J G. The Soil and Water Assessment Tool: Historical development, applications, and future research directions. Trans ASABE, 2007; 50(4): 1211-1250. doi: 10.13031/2013.23634.

[24] Mittelstet A R, Storm D E, White M J. Using SWAT to enhance watershed-based plans to meet numeric water quality standards. Sustain Water Qual Ecol, 2016; 7: 5-21. doi: 10.1016/j.swaqe.2016.01.002.

[25] Li Y, Urban M A. Water resource variability and climate change. Water, 2016; 8(8): 348. doi: 10.3390/w8080348.

[26] Mittelstet A R, Storm D E; Stoecker A L. Using SWAT to simulate crop yields and salinity levels in the North Fork River Basin. Int J Agric \& Biol Eng, 2015; 8(3): 110-124. doi: 10.3965/j.ijabe.20150803.950.

[27] USDA - NRCS. Urban hydrology for small watersheds. Technical Release 55. Washington, D.C.: USDA National Resource Conservation Service, 1986. Available at: http://www.hydrocad.net/pdf/ TR-55\%20Manual.pdf. Accessed on [2016-01-06]
[28] Hargreaves G L, Hargreaves G H, Riley J P. Agricultural benefits for Senegal River Basin, J Irrig Drain Engr; 1985; 111(2): 113-124. doi: 10.1061/(ASCE)0733-9437(1985)111:2(113).

[29] Arnold J G, Kiniry J R, Srinivasan R, Williams J R, Haney E B, Neitsch, S L. Soil and Water Assessment Tool, Input/Output Documentation Version 2012. Texas Water Resources Institute. TR-439. 654 pp. 2012. Available: http://swat.tamu.edu/documentation/2012-io/. Accessed on [2016-06-24].

[30] Doran J W, Schepers J S, Swanson N P, McCalla T M. Chemical and bacteriological quality of runoff from a central plains pastureland. U.S. EPA Report EPA-IAG-78-D-X0088. 1978. 43 p.

[31] Doran J W, Schepers J S, Swanson, N P. Chemical and bacteriological quality of pasture runoff. J Soil Water Conser 1981; 36(3): 166-171.

[32] USGS. National Elevation Dataset, 2002. U.S Geological Survey, Reston, VA. Available: https://ta.cr.usgs.gov/NED. Accessed on [2016-02-20].

[33] UNL. Land Use Mapping, Nebraska GIS Data, University of Nebraska-Lincoln, School of Natural Resources, Lincoln, NE. 2005. Available at: http://snr.unl.edu/data/geographygis/. Accessed on [2017-09-21].

[34] USDA. State Soil Geographic (STATSGO) database. Misc. Pub. 1492. U.S. Department of Agriculture, Natural Resource Conservation Service, National Soil Survey Center, Lincoln, NE, 1995. 113p. Available at: www.fsl.orst.edu/pnwerc/wrb/metadata/soils/statsgo.pdf. Accessed on [2016-04-18].

[35] Moriasi D N, Arnold J G, Van Liew M W, Bingner L R, Harmel R D, Veith $\mathrm{T}$ L. Model evaluation guidelines for systematic quantification of accuracy in watershed simulations. Trans ASABE, 2007; 50(3): 885-900. doi: $10.13031 / 2013.23153$

[36] Gupta H V, Sorooshian S, Yapo P O. Status of automatic calibration for hydrologic models: Comparison with multilevel expert calibration. J Hydraulic Engr, 1999; 4(2): 135-143. doi: 10.1061/(ASCE)10840699(1999)4:2(135).

[37] Nash J E, Sutcliffe J W. River flow forecasting though conceptual models. Part I - A discussion of principles. J Hydrol, 1970; 10(3): 282-290. doi: 10.1016/0022-1694(70)90255-6.

[38] Servat E, Dezetter A. Selection of calibration of objective functions in the context of rainfall-runoff modeling in a Sudanese savannah area. Hydrol Sci J, 1991; 36: 307-330. doi: 10.1080/02626669109492517.

[39] Abbaspour K C. User manual for SWAT-CUP, SWAT calibration and uncertainty analysis programs. Swiss Federal Institute of Aquatic Science and Technology, Eawag. Duebendorf, Switzlerland. 103p. 2013. Available: http://swat.tamu.edu/software/swat-cup/. Accessed on [2015-08-09].

[40] Van Liew M W, Garbrecht J. Hydrologic simulation of the Little Washita River Experimental Watershed Using SWAT. J Amer Water Resour Assoc, 2003; 39(2): 413-426. doi: 10.1111/j.1752-1688.2003.tb04395.x.

[41] Van Liew M W, Veith T L, Bosch D B, Arnold J G. Suitability of SWAT for the Conservation Effects Assessment Project: Comparison on USDA Agricultural Research Watersheds. J. Hydrologic Engineering, 2007; 12(2): 173-189. doi: 10.1061/(ASCE)1084-0699(2007)12:2(173).

[42] Gassman P W, Sadeghi A M, Srinivasan R. Applications of the SWAT model special section: Overview and insights. J Environ Qual, 2014; 43(1) 1-8. doi: 10.2134/jeq2013.11.0466.

[43] Bressiani D A, Gassman P W, Fernandes J G, Garbossa L H P, Srinivasan r, Bonumán B, et al. A review of Soil and Water Assessment Tool (SWAT) applications in Brazil: Challenges and prospects. Int J Agric \& Biol Eng, 2015; 8(3): 9-35. doi: 10.3965/j.ijabe.20150803.1765. 